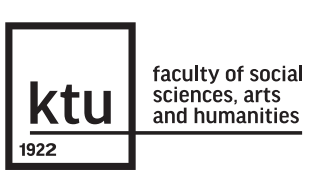

SAL 39/2021

Research Journal Studies about Languages pp. 33-40

ISSN 1648-2824 (print)

ISSN 2029-7203 (online)

DOI 10.5755/j01.sal.1.39.28184
LINGUISTICS / KALBOTYRA

Stoic Logic Allows Understanding a Priori Falsity in the Conditional

\begin{tabular}{l|l} 
Received $12 / 2020$ & Accepted 08/2021
\end{tabular}

Crossef http://dx.doi.org/10.5755/j01.sal.1.39.28184

HOW TO CITE: López-Astorga, M. (2021). Stoic logic allows understanding a priori falsity in the conditional. Studies about Languages / Kalbu studijos, 39, 33-40. http://doi.org/10.5755/j01.sal.1.39.28184

\title{
Stoic Logic Allows Understanding a Priori Falsity in the Conditional
}

\author{
Remiantis stoikų filosofija galima a priori suprasti sąlygos klaidingumą
}

MIGUEL LÓPEZ-ASTORGA, University of Talca, Chile

\begin{abstract}
An issue to explain in cognitive science is nowadays the case of certain conditionals that people seem to deem as a priori false. Those conditionals appear to be false by virtue of semantics: the meanings of their antecedents and their consequents seem not to admit any link between them. This is a problem because, from the point of view of classical logic, they are not always false; there can be situations in which they are true (as classical logic provides, whenever their antecedents are false, those conditionals in entirety are true). There are contemporary frameworks explaining this phenomenon (e.g., the theory of mental models). However, this paper tries to make the point that the solution might be already in ancient philosophy: in particular, in Chrysippus' logic. Thus, the paper describes in details (1) why those conditionals are controversial in classical logic and (2) the account that can be given for them from Chrysippus' philosophy. That account is based mainly on the Stoic idea that the negation of the second clause of a conditional should not be compatible with its first clause.
\end{abstract}

KEYWORDS: a priori falsity, Chrysippus of Soli, connexive implication, conditional, Stoic logic.

\section{Introduction}

There is a problem with some conditionals: they are not always false; however, people usually do not accept them. The basic aim of this paper is to address this problem. Those conditionals appear to be false under any circumstance (i.e., a priori false in the Kantian sense). Nevertheless, they are not, at least, if classical logic is taken into account. (1) is an example in this regard.

1 "If Mary has the flu, then she is healthy" (Quelhas, Rasga, \& Johnson-Laird, 2017, p. 1012).

Indeed, (1) seems to be a priori false, that is, a sentence true in no way. One might think that people should tend to reject it. Nonetheless, there are circumstances in which (1) can be true. Following classical logic, if Mary does not have the flu, and, therefore, the antecedent is false, the entire sentence is true (see, in addition to Quelhas et al., 2017, e.g., López-Astorga, 2020).

The problem is complex. Beyond what has been indicated, if the consequent of (1) is negated, the resulting sentence is a priori true, that is, true in every situation.

2 If Mary has the flu, then she is not healthy. 
According to the truth table of the conditional in classical logic, a sentence such as (2) would be false only if its antecedent were true and its consequent were false at once. Nonetheless, that situation is impossible (see, e.g., Quelhas et al., 2017; López-Astorga, 2020). As explained below, following Carnap (1947), (2) would be false only in the case of a state-description in which Mary had the flu and she were healthy. Given that a state-description with those characteristics cannot exist, (2) belongs to the kind of sentences Carnap (1947) names 'L-true', that is, true by virtue of the meaning of their words.

The difficulties associated to (1) can be expressed in accordance with Carnap's (1947) terminology too. (1) should be 'L-false', that is, false by virtue of the meaning of its words. However, it is not false in all of the state-descriptions. Obviously, in the state-descriptions in which Mary has the flu and she is not healthy, (1) is false. But it is true in every state-description in which Mary does not have the flu.

Based on this, a difficulty raises. It is hard to explain why people tend to reject sentences such as (1). Actually, several explanations can be given from current cognitive science. Most of them are directly based on the theory of mental models (for brief descriptions of some aspects of this theory, see, e.g., Byrne \& Johnson-Laird, 2020; Ragni \& Johnson-Laird, 2020; Torres Bravo \& Gairín Sallán, 2019). Three of them are numbered hereunder.

1 From the perspective of the theory, people consider, as iconic representations, the possibilities in which the sentences are true. Those possibilities are not necessarily equivalent to the situations in which connectives are true in classical logic (e.g., Johnson-Laird, 2012). In this way, under the theory of mental models, a sentence with a conditional structure (if..., then...) is not necessarily linked to characteristics logic gives conditionals. When a person uses a conditional sentence, that person does not always mean that the circumstance in which the antecedent is true and the consequent is false is impossible. What people do in those cases is just to take into account possible and impossible situations that semantics and pragmatics indicate (see also, e.g., Quelhas, Johnson-Laird, \& Juhos, 2010). Thus, in the case of (1), individuals can interpret that the impossible case is that in which both the antecedent and the consequent hold, the remaining three (the one in which the antecedent holds and the consequent does not, the one in which the antecedent does not hold and the consequent does, and the one in which neither the antecedent nor the consequent hold) being possible (in fact, following the theory of mental models, this is what Quelhas et al., 2017, seem to say).

2 On the basis of this, another alternative can be to propose that the logical structures of sentences are not the apparent ones, but those consistent with the possibilities that, in accordance with the theory of mental models, people detect. This is an idea the proponents of the theory generally reject (e.g., Johnson-Laird, 2010); they tend to consider logic not to be a relevant part of reasoning (see also, e.g., Khemlani, Byrne, \& Johnson-Laird, 2018). Despite this, (1) has been analyzed from this approach (López-Astorga, 2020).

3 One more explanation is the one that can be derived from papers such as that of Khemlani, Orenes, \& Johnson-Laird (2014). Khemlani et al. (2014) follow the theory of mental models too. Taking their experimental results into account, they argue that individuals can negate conditionals in a manner other than the one of classical logic. As indicated, in classical logic, the conditional is false when the true scenario is that in which the antecedent is true and the consequent is false. But Khemlani et al.'s (2014) idea is that the real mode individuals deny the conditional can be simply denying its consequent. Thereby, the negation of a conditional can be, in general, (3).

3 If the antecedent holds, then the consequent does not hold.

If this is the case, (1) is the denial of (2). Hence, if (2) is a priori true, (1) has to be a priori false (to a description of the exact argument that can be derived from Khemlani et al., 2014, in this regard, see also, e.g., López-Astorga, 2020).

There is no doubt that an important point related to all of this is that these three alternatives share the reference to the theory of mental models. That is relevant because it shows the role this theory plays in cognitive sciences nowadays. Nevertheless, the present paper does not try to develop that point. It is intended only to reveal that, for problems such as the one of (1), perhaps the solution was already in classical Greece. In particular, in the philosophy provided by Chrysippus of Soli. This paper develops a line of research proposed in other works (e.g., López-Astorga, 2016), which have applied the way Stoic logic understands the conditional to other problems or kinds of conditionals. Accordingly, because the arguments below will attempt to show that the difficulties linked to (1) can also be dealt with from Chrysippus' proposal, the intention of this paper is to offer one more piece of 
evidence of the potential the Stoic framework can have in linguistics and cognition. However, before explaining the solution that can be drawn from the Chrysippus' theses, the reasons why (1) is hard from the logical perspective will be explained in more details.

Philo of Megara, the Material Interpretation of the Conditional, and a Priori Truth and Falsity
Actually, the problem only exists if natural language in general and the conditional in particular are linked to classical logic. As indicated, that logic understands the conditional in an accurate way. The way was proposed by Philo of Megara (see, e.g., Mates, 1953; O'Toole \& Jennings, 2004) and it is known as the material interpretation of the conditional.

It is not hard to see what that interpretation is if any basic textbook of logic or philosophy of logic (e.g., Deaño, 1999; Fisher, 2008) is taken into account. The conditional has two clauses (antecedent and consequent). So, the combinations that can be provided between them by considering the scenarios in which they can be true or false are four.

a Both the antecedent and the consequent hold at the same time.

b The antecedent holds but the consequent does not.

c The antecedent does not hold but the consequent does.

d Neither the antecedent nor the consequent hold.

As pointed out, according to Philo's interpretation, there is only one case in which a conditional such as (4) can be false.

4 If the antecedent holds, then the consequent holds.

That case is (b), that is, when the first clause holds and the second one does not. An example can help understand this even better:

5 If you go to Sao Paulo, then you go to Brazil.

If you go to Sao Paulo, you necessarily go to Brazil, since Sao Paulo is in Brazil. Thereby, (a) can be admitted for (5). However, (b) cannot. Nobody can go to Sao Paulo without going to Brazil. On the other hand, (c) can also be accepted, as you might not go to Sao Paulo if you travel to Brazil. Finally, (d) is possible too; you can decide to go to neither Sao Paolo nor Brazil.

This is a very clear example. The thematic content of (5) allows easily noting the situations that are feasible. Nevertheless, the material interpretation of the conditional goes beyond. Under it, the conditional does not need to be a priori true, as (5) is. It establishes that, whenever the structure 'if...then...' is used, the intention is to express that the only unacceptable situation is (b). And this is even if there is no semantic relation between the two clauses. This last one is the case of a conditional such as (6).

6 If this is a triangle, then that is a square.

Following classical logic, although (6) is not a priori true, it should be considered true if this is a triangle and that is a square (a), this is not a triangle and that is a square (c), and this is not a triangle and that is not a square (d). The only circumstance in which (6) should be considered false is the case in which this is a triangle and that is not a square (b).

Nonetheless, apart from all the discussions that can rise from the explanations above (and, as, e.g., this paper shows, those discussions already began in ancient times), what is important now is that, from this perspective, (1) is a cognitive problem. Undoubtedly, (2) is not. Given that no one can have the flu and be healthy, (b) cannot happen in the case of (2). Therefore, it can be said that (2) is a priori true. However, (1) causes an obvious problem. For (1), while (a) is impossible and (b) is possible, (c) and (d) are possible. It might be the case that Mary does not have the flu and she is healthy, and it might also be the case that she does not have the flu and she is not healthy (she might have, e.g., another disease). Hence, it seems that, as pointed out by Quelhas et al. (2017), the framework of classical logic cannot account for the usual tendency to think that (1) is a priori false. To be that, (c) and (d) would have to be as (a), that is, impossible for (1) as well. 
Modal Logic, L-truth, and L-falsity
But, without leaving logic, other approaches can be embraced. One of those possible approaches can be the one of modal logic. One might object that there are several modal logics, and not only one. Nevertheless, for the aims of the present paper, a modal framework such as that given by Carnap (1947) can suffice to illustrate.

The essential in that framework is that it resorts, as habitual in modal logic, to possible worlds, or, in Carnap's (1947) terminology, state-descriptions. Possible worlds are much more than combinations of possibilities in which a sentence can be true (see, e.g., Johnson-Laird \& Ragni, 2019). Accordingly, they are much more than combinations such as (a), (b), (c), and (d). However, in modal logic, the truth or falsity of a sentence can change in different worlds (e.g., Hughes \& Cresswell, 1968). Thus, it is obvious that the system proposed by Carnap (1947) allows thinking about four groups of conceivable state-descriptions related to a conditional such as (4). In one of them, the antecedent and the consequent can be in the situation described in (a), that is, both of them are true. In the second one, those clauses can be in the situation described in (b), that is, only the if-clause is true. In the next one, those very clauses can be in the situation described in (c), that is, only the then-clause is true. Finally, in the fourth one, they can be in the situation described in (d), that is, none of the clauses is true.

If applied to (5), this means that the four groups of possible worlds to consider would be (7) to (10).

7 That in which you go to Sao Paulo and you go to Brazil (a).

8 That in which you go to Sao Paulo and you do not go to Brazil (b).

9 That in which you do not go to Sao Paulo and you go to Brazil (c).

10 That in which you do not go to Sao Paulo and you do not go to Brazil (d).

Nevertheless, as claimed, (b), that is, the only case in which the conditional can be false, is not possible for (5). Therefore, the state-descriptions included in (8) are not possible either, and it is impossible that (5) is false (possible worlds in which it is false cannot be thought). Thereby, (5) is a case of what Carnap (1947) denominates 'L-true sentence', namely, of sentence that is true because the definitions in the language for the words it contains make it that. And, given that (5) is a conditional, it can also be stated, following Carnap (1947) too, that its antecedent 'L-implies' its consequent, that is, that its antecedent implies its consequent because of the meanings of the words composing them.

This enables to understand why it can be accepted that (5) is an a priori true conditional. Nevertheless, the case of (6) is different. Now, the sets of possible worlds would be (11) to (14).

11 That in which this is a triangle and that is a square (a).

12 That in which this is a triangle and that is not a square (b).

13 That in which this is not a triangle and that is a square (c).

14 That in which this is not a triangle and that is not a square (d).

As also indicated, (b), or (12), does be possible for (6). Hence (6) is not L-true. At most, it could be what Carnap names 'F-true', that is, true in a factual sense. This is because (6) is true in worlds such as those in (11), (13), and (14), but false in those matching with (12). So, since (12) describes possible situations that could be real and are conceivable, only in the hypothetical case in which the current world had a structure akin to those in (11), (13), or (14), it could be said that (6) is true (or, if preferred, F-true). In the case of a state-description such as the ones in (12), it would be false (or, if preferred, keeping using Carnap's terminology, 'F-false').

On the other hand, (2) is L-true as well. As in the case of (5), the state-descriptions corresponding to (b), that is, the case in which the antecedent holds and the consequent is false, would be impossible. Its groups of worlds would be the following:

15 That in which Mary has the flu and she is not healthy (a).

16 That in which Mary has the flu and she is healthy (b).

17 That in which Mary does not have the flu and she is not healthy (c).

18 That in which Mary does not have the flu and she is healthy (d). 
Evidently, (2) is L-true because (16) cannot be admitted. So, it can be stated that the fact that Mary has the flu L-implies the fact that she is not healthy.

But there is no doubt that this perspective does not solve the problem at the beginning either. (1) could be L-false, that is, according to Carnap (1947), false in all the state-descriptions because of the meanings of the words it comprehends, only if no more worlds than those in (20) were possible for its clauses. Indeed, the sets for (1) would be these:

19 That in which Mary has the flu and she is healthy (a).

20 That in which Mary has the flu and she is not healthy (b).

21 That in which Mary does not have the flu and she is healthy (c).

22 That in which Mary does not have the flu and she is not healthy (d).

As pointed out, it is correct that cases such as those in (19) are not possible, and that cases such as those in (20) are possible. Nonetheless, the problem continues to be that the worlds involved in (21) and (22) are possible as well. Therefore, (1) is not L-false.

Nevertheless, the philosophical tradition offers a solution coming from ancient Greece. That is, in particular, the account that can be presented by resorting to the philosophy by Chrysippus of Soli and Stoicism. That account will be shown in the next section.

\section{The Account from} Stoic Logic
As it is well known, the Stoics did not understand the conditional in the same way as Philo of Megara, and, therefore, as classical propositional logic. Chrysippus required a connection between its two clauses (see, e.g., Barnes, Bobzien, \& Mignucci, 2008; O'Toole \& Jennings, 2004). For this reason, his manner to interpret the conditional, which was assumed by writers such as Boethius, is called the 'connexive view' of the conditional (e.g., Lenzen, 2019). In particular, ancient sources inform that the connexive view claimed a fight between the antecedent and the negation or denial of the second clause (Sextus Empiricus, Pyrrhoniae Hypotyposes 2, 111; Cicero, De Fato 12-16; Diogenes Laërtius, Vitae Philosophorum 7, 73; as secondary literature, see also, e.g., Gould, 1970).

According to McCall (1975), Chrysippus' idea can be captured by formula (23).

$$
23 \quad(\mathrm{p} \Rightarrow \mathrm{q}) \leftrightarrow \neg(\mathrm{p} \oplus \neg \mathrm{q})
$$

With other symbols, (23) appears in McCall (1975, p. 435) and, for example, Lenzen (2019, p. 538).

The symbols in (23) indicate the following: ' $\Rightarrow$ ' refers to the fact that the left formula (in this case, $p$ ) implies the right formula (in this case, q) fulfilling Chrisippus' requirement, that is, existing a connection between the two formulae. On the other hand, ' $\leftrightarrow$ ' is just the classical logical equivalence. This equivalence provides that, if its left formula (in this case, $p \Rightarrow q$ ) is true, its right formula (in this case, $\neg(p \oplus \neg q)$ ) has to be that too, and that, if its left formula is false, its right formula has to be that too. In other words, both formulae, the left and the right, have to be either true at the same time or false at the same time. ' $\neg$ ' represents the logical negation. Hence, it points out that the truth value of the formula following it should be changed. Thus, if, for instance, $p$ is true, $\neg p$ is false, and, if $p$ is false, $\neg p$ is true. Lastly, ' $\oplus$ ' stands for compatibility. It means that its left and its right formulae can be accepted at once, as it takes the idea of a connection established by Chrysippus of Soli into account.

However, 'compatibility' is still a very abstract concept. To address the problem of this paper, it is necessary to define it more specifically. Maybe another formula Lenzen (2019) offers after reviewing different works by Leibniz can be useful in this regard:

$$
24 \quad(\mathrm{p} \Rightarrow \mathrm{q}) \leftrightarrow \neg \diamond(\mathrm{p} \wedge \neg \mathrm{q})
$$

With other symbols, a formula akin to (24) is in Lenzen (2019, p. 548).

In (24), ' $v$ ' is the modal operator of possibility. It represents the fact that the formula following it (in this case, $p$ $\wedge\urcorner \mathrm{q})$ is true in at least a possible world. And ' $\wedge$ ' represents the logical conjunction, which is understood as a connective that can be true only in one scenario: when both its left formula (in this case, $p$ ) and its right formula (in this case, $\neg q$ ) are true at the same time. 
An interesting feature of (24) is that it can be transformed into (25). If it is assumed that ' $N$ ' is the modal operator of necessity, which expresses that the formula following it is true in every state-description, it is obvious that $\neg \diamond p$ is equivalent to $N\urcorner p$ (if $p$ is not possible, $\urcorner p$ is necessary; in other words, if there is no any possible world in which $p$ is true, $\neg p$ holds in all the possible worlds). So, (24) is equivalent to (25).

$$
25 \quad(\mathrm{p} \Rightarrow \mathrm{q}) \leftrightarrow \mathrm{N} \neg(\mathrm{p} \wedge \neg \mathrm{q})
$$

Considering (25), it is evident that (2) continues to be a priori true. If the conditional relation provided between the two clauses in sentences such as (4) is not the one corresponding to Philo's interpretation, but that represented by the symbol ' $\Rightarrow$ ' and described in (25), there is no doubt that it is impossible for (2) to be false. If ' $p$ ' denotes the fact that Mary has the flu and ' $q$ ' refers to the fact that she is not healthy (remember that the consequent is negated in (2)), it can be stated that there is no any state-description in which Mary can have the flu and she is healthy, which is exactly what the right part in (25) points out.

Nevertheless, the case of (1) is the inverse. Under Chrysippus' perspective, this last sentence is possible in no way. Whenever a person has the flu, that person is not healthy. Accordingly, the conditional relation between the fact that Mary has the flu (which would keep being ' $p$ ' in this case) and the fact that she is healthy (which, because the then-clause is not negated in (1), would be ' $q$ ' now), cannot fulfill what is established by the right clause in (25), that is, the requirement claimed by Chrysippus of Soli. Obviously, this is because the negation of the conjunction of the fact that Mary has the flu (p) and the fact that she is not healthy $(\neg q)$ is not necessary. That conjunction is possible. In fact, it is the only possibility if $p$ is true. Therefore, if the conditional is not understood as it is in classical logic, but as proposed by Chrysippus, (1) is undoubtedly a priori false.

\section{Conclusions and General Discussion}

Hence, it can be said that, if the material interpretation of the conditional is ignored and other present in the philosophical tradition (the one of Stoic logic) is assumed, the problem is resolved. The problem was that sentences such as (1) seem to be a priori false. In fact, people tend not to admit them. However, those sentences are not always false following classical logic. It is enough that their antecedents are false to be true. In Carnap's (1947) terminology, it can be said that they are not L-false. They are true in every state-description in which their first clauses do not hold. In this way, what the present paper has shown is that all of this is a problem only if the criterion offered by Philo of Megara, that is, the interpretation of the conditional assumed by classical logic, is accepted. If, on the contrary, the conditional is understood in the way Chrysippus of Soli proposed, those conditionals are a priori false. The key is that those sentences are conditionals in which there is no contradiction between the if-clause and the denial of the second clause.

It is true that there are several manners to account for that phenomenon based on the conceptual tools current cognitive science offers. Those are, for example, the manners proposed by the general theory of mental models (Quelhas et al., 2017), López-Astorga (2020), or Khemlani et al. (2014). Nonetheless, the point here has been that perhaps the necessary resources were already available long before, in ancient Greece and given by Chrysippus of Soli.

Thus, two points should be highlighted in this sense. On the one hand, as mentioned, this is not the first work showing that Stoic logic can solve problems related to human cognition. There are already some papers in this direction (e.g., López-Astorga, 2016). Those papers sometimes also resort to the way Chrysippus understood the conditional to explain why people do not accept certain kinds of conditional sentences (different from the one analyzed here, that is, the a priori false conditionals) or certain types of inferences including conditionals. On the other hand, it is not the first time that some connection between the theory of mental models and Stoic logic is provided either (see also, e.g., López-Astorga, 2016). This has allowed and continues to allow thinking that these two frameworks can share some characteristics. Clearly, examples in this regard can be that the content of sentences can be more important than their structures, and that maybe the contemporary explanations are not so far apart from accounts such as the one in this paper.

Accordingly, taking into account that Chrysippus' philosophy has been related to that of Carnap as well (e.g., López-Astorga, 2019), and that there are current theories speaking about links between the two clauses of the conditional too (e.g., Douven et al., 2018), it seems that two lines of further research are clear (at least, if the literature cited in this last section is considered). One of them refers to the potential of Stoic logic to deal with problems other than the one addressed here and those considered in previous works. Quelhas et al. (2017) 
use more controversial sentences that appear to be a priori false. But formulae such as (25) can also be easily applied to them, and it can be trivial to argue in that direction. Likewise, as said, the literature reveals that Stoic logic can account for some cognitive problems different from the one addressed in this paper as well (e.g., López-Astorga, 2016). So, maybe what can be interesting from now on is to explore whether there are even more cognitive phenomena that can be reviewed from the point of view presented by Chrysippus' interpretation of the conditional. The second possible line is related to the present time as well. It has to do with the possibility to find more intersections between Stoic logic and theories such as that of mental models. In this way, perhaps it would also be relevant to study to what extent essential theses in contemporary frameworks can come from classical ancient times. In any case, these two lines are already pointed out in a part of the references cited in this paper (e.g., López-Astorga, 2016).

\section{Acknowledgments}

This paper is a result of Project CONICYT/FONDECYT/REGULAR/FOLIO No 1180013, "Recuperación de las formas lógicas de los enunciados a partir de un análisis de las posibilidades semánticas a las que hacen referencia", supported by the National Fund for Scientific and Technological Development (FONDECYT, following its initials in Spanish), Government of Chile.

The author also thanks Project "PIA Ciencias Cognitivas, Centro de Investigación en Ciencias Cognitivas, Instituto de Estudios Humanísticos, Universidad de Talca".

References
1 Barnes, J., Bobzien, S., \& Mignucci, M. (2008). Logic. In K. Algra, J. Barnes, J. Mansfeld, \& M. Schofield (Eds.), The Cambridge History of Hellenistic Philosophy (pp. 77-225). Cambridge, UK: Cambridge University Press. https://doi.org/10.1017/ CHOL9780521250283.006

2 Byrne, R. M. J., \& Johnson-Laird, P. N. (2020). If and or: Real and counterfactual possibilities in their truth and probability. Journal of Experimental Psychology: Learning, Memory, and Cognition, 46(4), 760-780. https:// doi.org/10.1037/xIm0000756

3 Carnap, R. (1947). Meaning and Necessity: A Study in Semantics and Modal Logic. Chicago, IL: The University of Chicago Press.

4 Deaño, A. (1999). Introducción a la lógica formal. Madrid, Spain: Alianza Editorial.

5 Douven, I., Elqayam, S., Singmann, H., \& Wijnbergen-Huitink, J. (2018). Conditional and inferential connections: A hypothetical inferential theory. Cognitive Psychology, 101, 50-81. https://doi.org/10.1016/j.cogpsych.2017.09.002

6 Fisher, J. (2008). On the Philosophy of Logic. Belmont, CA: Wadsworth, Cengage Learning.

7 Gould, J. B. (1970). The Philosophy of Chrysippus. Albany, NY: State University of New York Press.https://doi.org/10.1163/9789004320369

8 Hughes, G. E., \& Cresswell, M. J. (1968). An Introduction to Modal Logic. London, UK: Methuen.

9 Johnson-Laird, P. N. (2010). Against logical form. Psychologica Belgica, 50(3/4), 193221. http://doi.org/10.5334/pb-50-3-4-193
10 Johnson-Laird, P. N. (2012). Inference with mental models. In K. J. Holyoak, \& R. G. Morrison (Eds.), The Oxford Handbook of Thinking and Reasoning (pp. 134-145). New York, NY: Oxford University Press. https://doi.org/10.1093/oxfordhb/9780199734689.013.0009

11 Johnson-Laird, P. N., \& Ragni, M. (2019). Possibilities as the foundation of reasoning. Cognition, 193. https://doi.org/10.1016/j.cognition.2019.04.019

12 Khemlani, S., Byrne, R. M. J., \& Johnson-Laird, P. N. (2018). Facts and possibilities: A model-based theory of sentential reasoning. Cognitive Science, 42(6), 18871924. https://doi.org/10.1111/cogs.12634

13 Khemlani, S., Orenes, I., \& Johnson-Laird, P. N. (2014). The negation of conjunctions, conditionals, and disjunctions. Acta Psychologica, 151, 1-7. https://doi.org/10.1016/j.actpsy.2014.05.004

14 Lenzen, W. (2019). Leibniz's laws of consistency and the philosophical foundations of connexive logic. Logic and Logical Philosophy, 28, 537-551. http://dx.doi.org/10.12775/ LLP.2019.004

15 López-Astorga, M. (2016). Paradoxical versus modulated conditional inferences: An explanation from the Stoicism. Manuscrito, 39(1), 61-72. https://doi.org/10.1590/01006045.2016.V39N1.MA

16 López-Astorga, M. (2019). The semantic method of extension and intension and the four criteria of the conditional described by Sextus Empiricus. Revista de Filosofía, 44(2), 253-261. https://doi.org/10.5209/resf.61161 
17 López-Astorga, M. (2020). Logical forms linked to certain a priori false conditionals. Comprendre, 22(1), 101-112.

18 Mates, B. (1953). Stoic Logic. Berkeley and Los Angeles, CA: University of California Press.

19 McCall, S. (1975). Connexive implication. In A. R. Anderson \& N. D. Belnap (Eds.), Entailment. The Logic of Relevance and Necessity. Volume I (pp. 434-446). Princeton, NJ: Princeton University Press.

20 O'Toole, R. R., \& Jennings, R. E. (2004). The Megarians and the Stoics. In D. M. Gabbay, \& J. Woods (Eds.), Handbook of the History of Logic, Volume 1. Greek, Indian and Arabic Logic (pp. 397-522). Amsterdam, The Netherlands: Elsevier. https://doi.org/10.1016/ S1874-5857(04)80008-6

21 Quelhas, A. C., Johnson-Laird, P. N., \& Juhos, C. (2010). The modulation of con- ditional assertions and its effects on reasoning. Quarterly Journal of Experimental Psychology, 63, 1716-1739. https://doi.org/ 10.1080/17470210903536902

22 Quelhas, A. C., Rasga, C., \& Johnson-Laird, P. N. (2017). A priori true and false conditionals. Cognitive Science, 41(55), 1003-1030. https://doi.org/10.1111/cogs.12479

23 Ragni, M., \& Johnson-Laird, P. N. (2020). Reasoning about epistemic possibilities. Acta Psychologica, 208. https://doi.org/10.1016/j. actpsy.2020.103081

24 Torres Bravo, L. D., \& Gairín Sallán, J. (2019). Detección de modelos mentales como posibilidades semánticas para el análisis del pensamiento social. Cultura, Lenguaje y Representación, XXI, 159-174. http://dx.doi. org/10.6035/clr.2019.21.9

\section{Santrauka}

\section{Miguel López-Astorga. Remiantis stoikų filosofija galima a priori suprasti sąlygos klaidingumą}

Viena iš problemų, kurią šiais laikais reikia paaiškinti kognityvinių mokslų srityje, yra tam tikros sąlygos, kurias žmonès a priori laiko klaidingomis. Šios sąlygos yra laikomos klaidingomis dèl semantinių ypatybių, t. y. sąlygų antecedentų ir konsekventų reikšmès neturi jokio tarpusavio ryšio. Tai sukelia keblumų, nes klasikinès logikos požiūriu jos ne visada yra klaidingos, t. y. gali būti situacijų, kai reikšmès yra teisingos (pvz., kaip teigiama klasikineje logikoje, esant klaidingiems antecedentams, šios sąlygos yra teisingos). Šiuolaikinès sistemos paaiškina šį reiškini (pavyzdžiui, mintinių modelių teorija), tačiau šiame straipsnyje bandoma atkreipti dèmesi j tai, kad sprendimas gali būti grindžiamas Chrisipo filosofija. Straipsnyje išsamiai aprašoma, kodèl šios sąlygos yra prieštaringos klasikinèje logikoje ir kokią informaciją apie jas galima pateikti iš Chrisipo filosofijos. Šis suvokimas iš esmès yra grindžiamas stoikų filosofija, kad implikacijos konsekvento neigimas neturètų atitikti antecedento.

About the Author

\section{MIGUEL LÓPEZ-ASTORGA}

$\mathrm{PhD}$ in Logic and Philosophy of Sciences, Professor at the Institute of Humanistic Studies "Juan Ignacio Molina", University of Talca, Talca Campus, Chile

Research interests

Philosophy of Language, relations between syntax, semantics, and pragmatics

\section{Address}

Instituto de Estudios Humanísticos "Juan Ignacio Molina", Universidad de Talca, Av. Lircay s/n, 3460000 Talca, Chile

E-mail milopez@utalca.cl

ORCID iD

https://orcid.org/0000-0002-6004-0587 